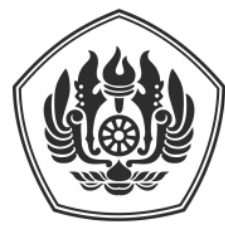

Padjadjaran Journal of International Law

ISSN: 2549-2152, EISSN: 2549-1296

Volume 3, Number 2, June 2019

\title{
Indonesia's New Model of Bilateral Investment Treaty: Comparison with Brazil
}

\section{Resha Rosana Putri ${ }^{*}$}

\begin{abstract}
In the past few years, there has been a surge in lawsuits against the mechanism for resolving international investment disputes through the Investors State Dispute Settlement (ISDS) forum proposed by foreign investors who are host states, including Indonesia. Most of the claims are caused by the policies of the host country which are intended to protect the basic rights of the people such as the right to health, the right to a healthy environment, taxes, as well as the minimum standard of wages for workers. This policy provides a loss for foreign investors and is considered a violation of the Bilateral Investment Treaty (BIT). BIT is often recognized to be detrimental to Indonesia, because it can disrupt the sovereignty of the country, especially when dealing with international disputes with foreign investors. This study uses a comparative juridical approach, comparing the BIT model in Indonesia with Brazil, namely Cooperation and Investment Facilitation Agreement (CIFA). Brazil was chosen because it succeeds to reform its investment regime, specifically on its BITs. The results obtained were that Indonesia had to change several provisions in its BITS, which has been regulated CIFA provisions in Brazil, which is not member of the ICSID Convention.
\end{abstract}

Keywords: BIT, CIFA, Investor State Dispute Settlement.

\section{Model Bilateral Investment Treaty Baru di Indonesia: Perbandingan dengan Brazil}

\begin{abstract}
Abstrak
Beberapa tahun terakhir, ada lonjakan tuntutan hukum terhadap mekanisme penyelesaian sengketa investasi internasional melalui Investor State Dispute Settlement (ISDS) forum yang diusulkan oleh investor asing yang menjadi host states, termasuk Indonesia. Sebagian besar klaim disebabkan oleh kebijakan negara tuan rumah yang dimaksudkan untuk melindungi hak-hak dasar masyarakatnya seperti hak atas kesehatan, hak atas lingkungan yang sehat, pajak, juga standar minimum upah pekerja. Kebijakan ini memberikan kerugian bagi investor asing dan dianggap sebagai pelanggaran Bilateral Investment Treaty (BIT). BIT seringkali dianggap merugikan bagi Indonesia, karena dapat mengganggu kedaulatan negara, khususnya ketika berhadapan dengan sengketa internasional dengan investor asing. Penelitian ini menggunakan pendekatan yuridis normatif dengan metode perbandingan, yaitu dengan membandingkan model BIT di Indonesia dengan Brazilia, yaitu Cooperation and Investment Facilitation Agreement (CIFA). Brazil dipilih karena merupakan
\end{abstract}

PADJADJARAN JOURNAL OF INTERNATIONAL LAW Volume 3 Number 2 Year 2019 [ISSN 2549-2152] [e-ISSN 2549-1296]

* Legal Assistant at Farida Law Office, Wirausaha Building Kav. C-5, South Jakarta, resharoshanaputri@gmail.com. 
negara yang berhasil melakukan reformasi terhadap rezim investasinya, khususnya pada BIT. Hasil yang diperoleh adalah bahwa Indonesia harus merubah beberapa ketentuan dalam BITs nya, seperti yang terkadung dalam CIFA di Brazil, yang bukan merupakan negara anggota dari Konvensi ICSID.

Kata Kunci: BIT, CIFA, Penyelesaian Sengketa Investor-Negara

\section{A. INTRODUCTION}

International relations that occur among subjects of international law, both between countries or between countries and the other subjects of international law naturally will face some difficulties along the way. The differences which exist in the background of the two countries, for example, both the legal system and the system of government have become one of the factors in differences of opinion and differences of views among the subjects of international law, especially in carrying out their life with other countries or other international legal subjects. ${ }^{1}$ These contrasting opinions among the subjects of international law may potentially cause international disputes. There is still no clear and rigid definition regarding international disputes, but the debate still arises when discussing whether disputes can be interpreted to be the same as conflicts in international law. ${ }^{2}$ In general, what is meant by international legal disputes is a dispute that can be solved based on international law. ${ }^{3}$ Limitation of what is meant by international legal disputes becomes important when the definition of this dispute is also often compared to political disputes. International Investment Arbitration is a procedure for solving disputes between foreign investors and host states (also called Investor-State Dispute Settlement or ISDS). The possibility for foreign investors to sue a host country is a guarantee for foreign investors who, in the case of disputes, will have access to an independent and quality arbitrator who will solve the dispute and make the award carried out. This allows foreign investors to bypass national jurisdictions that might be considered to be biased or lacking in independence, and to solve disputes in accordance with the different protections given under international agreements. ${ }^{4}$ ICSID is an international investment arbitration body established by the World Bank with the intention of solving disputes especially regarding investment disputes among member countries. By all means, not all the countries can resolve disputes in ICSID investment, unless the country has ratified the 1965 Washington Convention. Indonesia as one of the developing countries that is quite active in foreign investment has ratified this convention through Law No. 5 of 1968 concerning Settlement of Disputes between States and Foreign Citizens concerning Investment.

In the Indonesian context, the regulation regarding foreign investment was regulated

Corsin Bisaz, The Concept of Group Rights in International Law, Leiden: Martinus Nijhoff Publishers, 2012, p. 28.

Ibid., p. 112

Ibid.

Ibid. 
in Law No. 1 of 1967 concerning Foreign Investment as amended by Law No. 11 of 1970 concerning Amendments and Additions to Law No. 1 of 1967 concerning Foreign Investment and Law No. 6 of 1968 concerning Domestic Investment as amended by Law No. 12 of 1970 concerning Amendments and Additions to Law no. 6 of 1968 concerning Domestic Investment because the development of the era and the law were deemed to be no longer suitable with the need for accelerated development and the development of national law. ${ }^{5}$ Currently, the law was changed to Law No. 25 of 2007 concerning Investment. The law brings together regulations regarding foreign investors and domestic investors. In other words, this Investment Law is intended to provide legal certainty between the investors and the host state. ${ }^{6}$

According to UNCTAD (1995), there are eight bilateral and multilateral agreements which usually apply to investments, namely Provisions on Capital Movement (PCM), Provisions on Foreign Borrowing (PFB), Double Taxation treaties (DTT), Insurances Guarantees in MIGA, Washington Convention on the Settlement of Investment Disputes (WCSID), Preferential Trade Agreement (PTA), and Bilateral Investment Treaties (BIT). ${ }^{7}$ In bilateral cooperation, countries establish relationships with reciprocity principal. ${ }^{8}$ In terms of investment, bilateral agreement

USA Global Investment Centre, Indonesian Investment and Business Guide, USA: USA International Publications, 2007, p. 4.

$6 \quad$ Katharina Diel, Towards Consistency of International Investment Jurisprudence, Leiden: Koninklijke Brill, 2017, p. 103.

7 Rashmi Banga, Government Policies and Investment Agreements on FDI Inflows, India: Indian Council on International Economic Relations, 2003, p. 100. institutions have been known since the decade of the 1970s in the framework of the International Guarantee Agreement (IGA). ${ }^{9}$

In Indonesia, there have been around 66 bilateral agreements which have been signed, but in the implementation, there are several obstacles which resulted as a dispute between Indonesia and other foreign countries. ${ }^{10}$ There are a number of cases which in reality the Indonesian government was sued by foreign investors due to the foreign investors' policies made by the Indonesian government to harm them. ${ }^{11}$ The investment protection by the International Investment Agreement (IIA) is carried out by Indonesia through the Investment Improvement and Protection Agreement (TIPI), where bilateral Investment Agreement (BIT) is one of them. ${ }^{12}$ Another form is the Comprehensive Economic Partnership Agreement (CEPA), as well as the complete Regional Comprehensive Economic Partnership (RCEP) containing Investor State Dispute Resolution (ISDS). Furthermore, to attract more investors, Indonesia also plans to join the Trans Pacific Partnership Agreement (Hasan, 2017). There are also other agreements such as the Agreement with Investment Conditions (TIP), Trade Relations Agreement (TRA), Free Trade Agreements (FTA), Trade and Cooperation Agreement (TCA) and Cooperation Agreement (CA). It can be conveyed that the

9 BKPM, Development of Investment and Improvement Agreements (P4M) and P4M Settlement Priorities Between Indonesia-Partner Countries, Jakarta: Report, 2013, p. 133.

10 Ibid.

11 Ibid.

12 Ibid. 
current government priority scale is to be approved or launched in negotiations and improvements of international economic cooperation given in the investment sector, such as: the Indonesia-EU Comprehensive Economic Partnership Agreement (IEU-CEPA); Indonesia-Australia Comprehensive Economic Partnership (IA-CEPA); IndonesiaEurope Free Trade Association (IEFTA-CEPA); and the Trans-Pacific Partnership Agreement (TPP); ASEAN-Japan Economic Partnership Agreement (AJEPA) and Regional Comprehensive Economic Partnership (RCEP). ${ }^{13}$ The government believes this can provide a significant attraction for foreign investors to come to Indonesia.

BIT is one of the most commonly used investment agreements forms of IIA by Indonesia. Theoretically, BIT must be able to benefit both parties, based on the principle of reciprocity, equality and non-intervention in international law. However, in practice the existence of BIT is much complained by developing countries including Indonesia. First, the substance of the majority of BITs is imbalance. Almost all articles in the BIT contain enormous protection and rights for foreign investors; on the contrary there are so many obligations for the host country. There is no protection and rights for the host. It is no exaggeration to say that the IIT has reduced the principle of equality in international law, because the host country does not enjoy the actual benefits of the agreement. Second obligation, BIT eliminates the sovereignty of

13 In August 2012, the 16 Economic Ministers endorsed the Guiding Principles and Objectives for Negotiating the Regional Comprehensive Economic Partnership. The RCEP negotiations were launched by Leaders from 10 ASEAN Member States (Brunei Darussalam, Cambodia, Indonesia, Lao PDR, Malaysia, Myanmar, the Philippines, the state to adopt policies that protect the public interest. The host country will be prosecuted before the Investor-State Dispute Resolution (ISDS) when policies to protect public interests are considered inconsistent with commitments in international investment agreements and harm foreign investors.

Based on this explanation, it is not surprising that there are many parties who question the urgency of the use of BIT and even recommend the government to end the agreement. Doubts about the need for BITs are resolved through an arbitration institution;

1. The second clause requires "... a conciliation or arbitration by the Center ..." sympathetic consideration but does not require an agreement from the parties.

2. The third type of clause, which requires the recipient country "... to be assent to any demand on the part of the nation to submit for conciliation or arbitration any dispute arising from the investment" and;

3. The fourth type of clause, that is, the clause that gives authority from ICSID as a media for dispute resolution if a dispute arises between the parties in the future. This type is usually found in BITs made by the British Government.

Awareness of the efficiencies in resolving disputes between investors with host country also occur because of the temporary nature

\footnotetext{
Singapore, Thailand and Viet Nam) and six ASEAN FTA partners (Australia, People's Republic of China, India, Japan, Republic of Korea, and New Zealand) during the $21^{\text {st }}$ ASEAN Summit and Related Summits in Phnom Penh, Cambodia in November 2012.
} 
of arbitration courts (ad hoc), lack of transparency and legitimacy. Problems arise because of jurisprudence in this court is very diverse and there is no appeal process thus reducing the standard of truth and legal consistency. Although BITs are claimed to be reciprocal agreements between parties bound in it, in fact, the BITs agreement is not symmetrical. BITs look equal because it regulates that citizens and companies of each country which can invest in each other's regions with equal protection. ${ }^{14}$ Even so, most signed BITs are between developed countries and developing countries. Imbalance is created between the two with their relative bargaining position of each country and the direction of capital transfers. Usually, industrial countries become a source of investment while developing countries become recipients.

\section{B. INDONESIA'S NEED FOR A NEW BIT MODEL}

Indonesia has shown dissatisfaction with the current situation of investment agreements, and some in Indonesia have expressed reluctance to ISDS in particular. Earlier this year, the Dutch embassy in Jakarta announced that the Indonesian Government had told the Netherlands that they intended to end the Dutch-Indonesian BIT, starting July 1, 2015, when the BIT ended. The Dutch embassy also stated that the Indonesian Government had said it would terminate 67 BITs. ${ }^{15}$

Dilip K. Das, Loc.Cit.

15 Steffen Hindelang and Markus Krajewski, Shifting Paradigms in International Investment Law: More Balanced, Less Isolated, Increasingly Diversified, Oxford: Oxford University Press, 2016, p. 328.
Since then, there has been extensive discussion about the intentions of the Indonesian Government and what might motivate his decision to cancel the Dutch BIT. It has been suggested that, at least in part, the case of Churchill Mining PLC and Planet Mining Pty Ltd v. Republic of Indonesia may have motivated the Government of Indonesia to review the current portfolio of agreements. Churchill's claim, which has raised concerns in Indonesia, is worth more than $\$ 1$ billion, not including interest. ${ }^{16}$ Indeed, there is a firm call for Indonesia to immediately withdraw from the ICSID and continue to treat BIT carefully. This reason for caution includes the need to treat foreign and domestic investors equally and to restrain the Government as a result of international claims filed against them. More specifically, there is a view that, given its current economic strength, Indonesia no longer needs to abandon its autonomous arrangements to attract foreign investment. ${ }^{17}$

The termination of its BIT by Indonesia does not mean the full withdrawal of all obligations and investment protection mechanisms. ${ }^{18}$ Existing investors will continue to be protected by "survival clauses" that have been included in many BITs. For example, under the Dutch-Indonesian BIT, investment under BIT will be protected by a 15-year sunset period after the termination of BIT. Furthermore, even if all the BITs are terminated, Indonesia will still be subject to its obligations under the ASEAN Comprehensive Investment Agreement and

16 UNCTAD, "Reform of Investor-State Dispute Settlement: In Search of a Roadmap", Issues Note No. 2, June 2013, p.1.

17 Ibid.

$18 \quad$ Ibid, p. 2. 
the ASEAN-Australia-New Zealand Free Trade Agreement. ${ }^{19}$

As a result, it seems that Indonesia's response (especially in the case of Churchill and Planet, and generally its determination to overturn the Netherlands BIT and review others) is more a reaction to the BIT provisions in practice and its application than in principle. Investor protection, this position is supported by President Yudhoyono's statement after the decision of Churchill's jurisdiction, when he railed against greed and "looting foreign companies", and did not conflict with the reasonable rights of investors. ${ }^{20}$ Whatever might be the real catalyst for notices of cancellation and review, it seems clear that Indonesia's actions have been driven by a number of related factors, including concerns about what it considers as increasing exposure to investor claims in international arbitration, national legislation and overriding domestic justice is considered a reckless claim, and IIA is obsolete.

As Anthony Crockett pointed out, most Indonesian BITs were signed before the socalled "new generation" of BITs (as exemplified by the 2004 US BIT Model) and as such would be seen as representatives of "old generation BITs" and lack of officers (such as those shown from an Indonesian perspective by the results of the Planet jurisdiction case. ${ }^{21}$ The Ambassador also stated that a consistent

19 James Headley, A. Reitzig, and J. Burton, Public Participation in Foreign Policy, London: Palgrave Macmilan, 2012, p. 51.

20 Julien Chaisse and Tsai-yu Lin, International Economic Law and Governance: Essays in Honour of Mitsuo Matsushita, Oxford: Oxford University Press, 2016, p. 157.

21 Pasha L. Hsieh and Bryan Mercurio, ASEAN Law in the New Regional Economic Order: Global Trends and Shifting template is needed to guide the Indonesian BIT negotiators. The Indonesian government has also explained that its review is intended to lead to the development of the BIT Model. This raises the problem of the approach or policy direction that might be taken by Indonesia in relation to this BIT Model, as well as the inclusion of BIT and ISDS provisions in wider trade agreements. Losari and EwingChow suggest that, procedurally, there are three options for Indonesia to stop existing BITs, namely: ${ }^{22}$

1. Terminating BIT which passes unilaterally by means of notification (as happened with the DutchIndonesian BIT) and renegotiates new ones;

2. Terminating the old BIT consensually with another party (as it seems to happen with the Singapore-Indonesia BIT) and renegotiate a replacement agreement; or

3. Old BIT renegotiations with a view to changing clauses to clarify them further.

The problem with the first option is that investments made before the termination date still enjoy protection for the next period (usually fifteen years) in accordance with the provisions in the survival clause. ${ }^{23}$ The second and third options can allow for direct conclusions from the previous provisions, including the provisions of the survival clause, on mutual agreement and formalization

Paradigm, Cambridge: Cambridge University Press, 2019, p. 277.

22 Zachary Douglas, Joost Pauwelyn, and Jorge E. Viñuales, The Foundations of International Investment Law: Bringing Theory into Practice, Oxford: Oxford University Press, 2014, p. 469

$23 \quad$ Ibid. 
between the two parties from a replacement agreement or amended clause. However, as Losari and Ewing-Chow show, the second and third options can really be taken only if Indonesia already has its BIT Model. ${ }^{24}$ At the same time, their success is entirely dependent on the consent of others to give the proposal to Indonesia.

\section{CIFA: BRAZIL'S NEW BIT MODEL}

Brazil's experience with investment agreements is a stark contrast to other countries. When most states promoted it, Brazil refused to do so. For this reason, the promotion of government Cooperation and Investment Facilitation (CIFA) has recently been interesting agreement for the investment climate in Brazil. ${ }^{25}$ In 1991, Brazil started one of the largest privatization programs in the world, selling assets worth more than US $\$ 100$ billion. Seventeen years later and with the Gross Domestic Product (GDP) which ranks tenth in the world, Brazil is an industrial power which, according to the World Bank, experiences stable economic growth, a fact that has been partly facilitated by Brazil to increase the implementation of openness principal for the investment regime. In January 2006, Brazil realized about US $\$ 88$ billion in sales revenue and around US $\$ 18$ billion in debt transfers as a result of the privatization program. Foreign investment accounts for around $48 \%$ of that total.

24 Chester Brown, Commentaries on Selected Model Investment Treaties, Oxford: Oxford University Press, 2013, p. 543.

25 Anthea Roberts, et.al (eds.), Comparative International Law, Oxford: Oxford University Press, 2018, p. 123.

26 Geraldo Vidigal, "Brazil's New Model of Dispute Settlement for Investment: Return to the Past or
Regardless of the importance of foreign investment in the economy and unlike other South American countries, Brazil is not a party to the bilateral investment agreement (BIT) and has not ratified the ICSID Convention. ${ }^{26}$ One reason for Brazil's reluctance to commit itself to such an agreement is legal uncertainty. In particular, there is controversy in Brazil with regard to whether ratification of such agreements is prohibited under Brazilian law on the grounds that it impedes the sovereign rights of the state. However, others noted that Brazil could legally, and in fact had previously agreed to bind foreign arbitration by routinely entering into contracts that provided the dispute resolution mechanism. Different with the majority of its neighboring countries in Latin America, Brazil has never ratified international investment agreements containing the ISDS clause (between 1994 and 1999 , the country signed a total of 14 BITs, but never ratified them) and never adopted the ICSID Convention. ${ }^{27}$ Provisions for resolving disputes in two bilateral agreements on applicable investments, both of which were signed before the agreement between Germany and Pakistan which formalized the ISDS, were of an inter-country nature and were not mandatory. There are two reasons for Brazil not to comply with an investment regime dominated by ISDS. ${ }^{28}$ First, there are several doubts regarding the constitutional barriers to the Brazilian state's submission to investment arbitration.

Alternative for the Future?", Journal of World Investment and Trade, Vol. 19, Issue 3, 2018, p. 477.

$27 \quad$ Ibid.

28 See Maria A Gwynn, "South American Countries' Bilateral Investment Treaties: A Structuralist Perspective", JIDS, Vol. 6, Issue 1, 2015, p. 101-102. 
Second, the state is able to maintain its appeal to invest in a way that does not tie it to the ISDS. Indeed, Brazil is consistently ranked among the top 10 recipients of foreign direct investment (FDI) worldwide. Even in the 2014 and 2015 crisis years, Brazil ranked 4 th in the world among FDI recipients. At least for countries with Brazilian characteristics, it appears that IIA is not decisive for attracting FDI.

Brazil's absence from the international investment law regime does not mean that foreign investors are not protected in this country. ${ }^{29}$ Especially since the enactment of the arbitration law in 1996, contractual arbitration has increasingly been used as a means of resolving disputes in state contracts. A number of decisions by the Brazilian high court have confirmed the legality of the arbitration clause in the state contract and the enforcement of the arbitration award against the state. However, regarding the international investment regime, Brazil's position remains an attentive observer. Moreover, in 2015, Brazil signed six CIFAs with Mozambique, Angola, Malawi, Mexico, Colombia and Chile. ${ }^{30}$ And in 2016, Brazil signed a broader agreement with Peru in the framework of 'Economic and Trade Expansion Agreement' - which regulated the same provisions relating to investment. ${ }^{31}$ Brazil has stated that it is intended to create incentives for mutual investment through a mechanism of intergovernmental dialogue

29 Thomas Schultz and Cédric Dupont, "Investment Arbitration: Promoting the Rule of Law or OverEmpowering Investors? A Quantitative Empirical Study", European Journal of International Law, Vol. 25, Issue 4, 2014, p. 1147 and 1151.

30 Andreas Kulick, Global Public Interest in International Investment Law, Cambridge: Cambridge University Press, 2012 , p. 56. for investors and the state to provide an alternative institutional model for the prevention and resolution of disputes.

Overcoming traditional Brazilian resistance to the IIA, CIFA created a new regime for FDI protection, not including the ISDS and instead established a hybrid system of dispute prevention and arbitration mechanisms between countries. CIFA establishes a legal framework for the governments of countries of origin to defend the interests of citizens, negotiate directly with, or initiate arbitrary proceedings against, the host country government. Arbitration is compliance only rather than compensating investors for violations. ${ }^{32}$

There are two elements consisted in Brazil's ISDS in CIFA, such as: ${ }^{33}$

\section{Dispute Prevention (Focal Points and Joint Committee)}

A number of CIFA provisions relate to the prevention of disputes, which aim to avoid other avenues to litigation. For this purpose, one 'focal point or ombudsman' for each party and another one is Joint Committee. Focal Points are domestic government institutions of the parties, while the Joint Committee is the organ of agreement for political decision making, and is responsible for managing collective agreements and is responsible for

$31 \quad$ Ibid

32 Frank J Garcia (et.al), "Reforming the International Investment Regime: Lessons from International Trade Law", Journal of International Economic Law, Vol. 18, Issue 4, 2015, p. 861 and 874

33 Michael Waibel (et.al), The Backlash Against Investment Arbitration. Perceptions and Reality, The Hague: Kluwer, 2010, p. 77. 
managing relevant agreements. ${ }^{34}$ Focal Points are government instruments that must be implemented to ensure the proper implementation of CIFA, which serves as the first contact point for foreign investors in the host country. The creation of the CIFA focal point was inspired by South Korea's positive experience with the investment ombudsman. The Office of the South Korean Foreign Investment Ombudsman (OFIO) provides post-investment services for foreign investors and issues regarding finance, taxation, accounting, intellectual property rights, construction issues and labor or employee' issue. ${ }^{35}$

If the works of Focal Points are not successful, CIFA also requires that the question that is of interest to investors is before the start of the dispute. The Joint Committee must examine disputes; hear parties, as well as investors and governments and non-government entities involved in disputes; and issuing public reports, which include the Joint Committee, also seen in other international agreements, 60 playing an important institutional role in CIFA. They provide ways to resolve potential conflicts without going into litigation. The big role of the Joint Committee and Focal point is the perspective underlying CIFA: providing institutions and instruments for cooperation between countries, bringing

Ibid.

Thomas W Wälde, "Improving the Mechanisms for Treaty Negotiation and Investment Disputes: Competition and Choice as the Path to Quality and Legitimacy" in Karl P Sauvant (ed), Yearbook on International Investment Law \& Policy 2008-2009, Oxford: Oxford University Press, 2009, p. 505, 543. elements of diplomacy to the investment protection regime.

\section{Dispute Settlement}

The Brazil-Angola CIFA stipulates that, if a dispute cannot be resolved through negotiations or with a recommendation from the Joint Committee, the parties may request assistance from the state-tostate arbitration mechanism, which means that arbitration will require a new agreement between the two parties. Under the CIFA Brazil-Mozambique and Brazil-Malawi, disputes that are not resolved by agreement can be submitted to arbitration 'whenever deemed comfortable by the parties'. ${ }^{36}$ This agreement refers to the state-to-state arbitration mechanism 'to be formed by the Joint Committee'. Although the words in the provision do not appear to preclude the establishment of a further mechanism in which arbitration is compulsory, this seems to require a new agreement between the parties. In contrast, the CIFA American Latin American feature 'is a dispute settlement provision that used to be and forms a two-stage process. In the first stage, the Joint Committee must be officially arrested with a dispute; given a period of 60 days to issue a report on the matter. If this does not resolve the dispute, one party may unilaterally request an

36 See Charles N Brower and Sarah Melikian, "We Have Met the Enemy and He Is Us! Is the Industrialized North Going South on Investor-State Arbitration?", 2015, p. 19; Catherine M Amirfar, "Treaty Arbitration: Is The Playing Field Level and Who Decides Whether It Is Anyway?" in Albert Jan van den Berg (ed), Legitimacy: Myths, Realities, Challenges, The Hague: Law International, 2015, p. 755775 . 
arbitration, carried out (in the absence of an agreement between the parties to bring disputes to the institutional mechanism) before the ad hoc arbitration court. Importantly, a backward mechanism is available to prevent parties from thwarting dispute resolution procedures by failing to appoint arbitrators. If the parties fail to appoint members to the court or if the arbitrator appointed by the party fails to jointly appoint a seat within the specified deadline, this appointment must be carried out by an international institution.

The established CIFA mandatory arbitration mechanism seems to refer to the language of the WTO Dispute Settlement Understanding (DSU). Article 3 of Annex I of the Brazil-Chile CIFA, which sets out the reference provisions for arbitration courts, describes them as: ${ }^{37}$

"To examine, methods and objective agreements are made from requests to form an arbitral tribunal, and to make facts and legal findings, or not the actions referred to in accordance with the Agreement."

This language echoes Article 7.1 of the DSU, which is set as the standard reference frame for WTO panels, a problem referred to by the WTO adjudication. Article 11 The DSU adds that the panel must make an objective assessment of the problem before that,

37 Karl Sauvant and Federico Ortino, Improving the International Investment Law and Policy Regimes: Options for the Future, Finland: Ministry of Foreign Affairs of Finland, 2013, p. 44.

including an objective assessment of the facts and conditions of compliance with the relevant closed agreement. Finally, Article 12.7 of The DSU stipulates that the panel report must describe the findings of the facts, the findings of the relevant provisions and basic recommendations, and the recommendations that make them. ${ }^{38}$

Apart from the language taken from the text, CIFA shared with the WTO, the purpose of communication, stated in Article 3.7 of the DSU, CIFA of BrazilMexico and Brazil-Peru stated this goal explicitly, while CIFA Brazil-Chile and Brazil-Colombia used words that slightly different, provided that the purpose of arbitration is to provide compensation: ${ }^{39}$

"The purpose of the arbitration is to approve it with an arbitration award so as not to comply. The parties may not agree that the arbitrator considers the existence of damage and stipulates in the award of compensation for this damage. If the award determines monetary compensation, the party receiving this compensation must transfer it to reduce litigation costs, following each party's domestic procedures."

The difference between these two is different and, apparently, alternative solutions are available after the discovery $39 \quad$ Ibid. 
of violations. ${ }^{40}$ One of them is a formal statement about the obligation to adjust to the agreement, an action that is considered inconsistent. Requires compensation payments for damage. ${ }^{41}$ The same results arise from the provisions in the Brazil-Colombia $\mathrm{Cl}$ preventing the arbitration court from awarding compensation for damage unless the parties sign a special agreement for this effect. If the compliance obligation in the CIFA is interpreted as equivalent in the WTO law, the decision that finds the violation will only require the obligation for the offender to adjust and stop the behavior of CIFA which is inconsistent with the prospective effect. The country found in the violation will be able to fully comply with the decision by revoking the relevant action ex nunc (in case of a non-policy violation but an action, he cannot repeat the action). The legal situation and transfer of property generated by these actions will be fully maintained. ${ }^{42}$

This interpretation will produce three effects. First, it would overturn a number of substantive provisions in the CIFA, making takeovers without de facto compensation permitted when carried out through one-time actions whose effects could later be considered to be crystallized in the past. Secondly, it can

40 Daniel M C Barbosa and Pedro Martini, "Two Sides of the Same Coin: To What Extent Is Arbitration with the Brazilian Administration Similar to Investment-Treaty Arbitration?" in Daniel de Andrade Levy, et.al (eds.), Investment Protection in Brazil, Netherlands: Wolters Kluwer Law and Business, 2013, p. 37-59

$41 \quad$ Ibid.

42 Folla Adeleke, International Investment Law and Policy in Africa: Exploring a Human Rights Based Approach to produce a perverse incentive for the government that seeks to extract leases from foreign investors: while actions aimed at extracting leases from time to time (for example, higher taxes) are subject to CIFA repairs, one-time collection will be protected from drugs. Third, this interpretation will make CIFA arbitration unattractive compared to other forms of investment protection.

Competition from other forms of dispute resolution is very significant. If the CIFA court is only empowered to provide limited compensation and different international courts have jurisdiction over disputes (which is the case for ICJ between some (IFA), ${ }^{43}$ investors might find it more interesting to convince their home countries to take disputes with adjudicators where they can get effective recovery - compensation or retrospective restitution - rather than CIFA arbitration. Or, investors can choose to ensure they are more effectively protected by contract arbitration. Confidentiality of contract arbitration will usually mean that arbitration courts can still be established and provide compensation, without transparency which usually accompanies arbitration between countries, and which is increasingly needed in investor-state arbitration. ${ }^{44}$

Investment Regulation and Dispute Settlement, London: Roudledge, 2017, p. 47.

43 Makane Moïse Mbengue and Stefanie Schacherer, Foreign Investment under the Comprehensive Economic and Trade Agreement (CETA), Switzerland: Springer, 2019, p. 259.

44 See Fabio Morosini and Michelle Ratton Sanchez Badin, "The Brazilian Agreement on Cooperation and Facilitation of Investments: A New Formula for International Investment Agreements?", Investment Treaty News, 
The provisions in CIFA Brazil-Mexico and Brazil-Colombia which require the consent of the parties to give the compensation do not affect the task of reparation, which arises only because of the fact of the violation. ${ }^{45}$ On the contrary, this provision ensures the primacy in the practice of restoring compensation for compensation. While restitution has generally been affirmed by the court and the arbitral tribunal as the main remedy for violations, adjudicators often emphasize this in principle, only to conclude that restitution is impractical or unwanted and compensates. In arbitration that occurs under CIFA, only parties - namely the state party - can decide that compensation for restitution is undesirable and that compensation is the right compensation. In other cases, courts that decide to apply general international law can determine compensation to be paid, and even determine the amount. ${ }^{46}$

Even in the absence of such strict provisions, some investment arbitrators have interpreted the advantages of restitution as means that compensation must be an additional drug. In Texaco $v$. Libya, the arbitral tribunal ordered Libya to return to the claimants of its oil operations, stating that restitution is 'normal sanctions for not carrying out contractual obligations ... cannot be

2014, accessed from

https://www.iisd.org/itn/2015/08/04/the-brazilianagreement-on-cooperation-and-facilitation-ofinvestments-acfi-a-new-formula-for-internationalinvestment-agreements/.

45 Markus Krajewski and Rhea Tamara Hoffmann, Research Handbook on Foreign Direct Investment, Chaltenham: Edward Elgar, 2019, p. 576. applied only insofar as recovery of the status quo ante is impossible'. In Goetz v. Burundi, the ICSID arbitration court stated that Burundi could provide 'adequate and effective compensation' to the plaintiff, or that it could give them restitute in the integrum. In Arif $v$. Moldova, the ICSID arbitration court ordered Moldova, at Moldova's request, 'to allow the Applicant to open and operate duty-free shops at Chisinau International Airport without undue interference'. ${ }^{47}$

CIFAs are not the only attempt to react to perceptions beyond the reach of the ISDS. In a shift marked by the signing and subsequent revisions of the US-South Korea FTA, ${ }^{48}$ the BIT and FTA increasingly determined that countries maintain extensive regulatory space and limit the possibility of investment claims. In addition, many IIAs contain chapters that limit the use of regulatory powers that are deemed undesirably, preventing the government from adopting lose labor standards and the environment to attract investment. In most cases, the provision is still insufficiently enforced and the accuracy of other more established obligations is found traditionally in IIA, although CPTPP, for example, provides the possibility of (state-to-state) dispute

46 Françoise Nicolas (et.al), "Lessons from Investment Policy Reform in Korea", OECD Working Papers on International Investment 2013, Vol. 02, 2013, p. 24-25.

47 Ibid.

48 Rubens Duarte, "The Role of Brazil in the Multilateral Financial System: An Analysis of Domestic and Structural Factors (2003-2015)", The Journal of the Brazilian Political Science Association, Vol. 11, Issue 3, 2017, p. 98. 
resolution regarding this obligation. ${ }^{49}$ Overall, the idea that design IIA can be an important element in ensuring that investment functions to generate economic growth, and achieve socially desirable goals in other fields, has garnered support in capital exporting countries, which traditionally refuse to impose constraints on investor. ${ }^{50}$

Thus, this increase in communication provides incentives and information needed for the government to file a claim to the court. Regarding Brazil, the WTO litigation led participation in the formation of important public-private partnerships for dispute resolution, enabling it to challenge a number of steps before the WTO adjudicators, the most significant in the field of subsidies. Other CIFAs are active in WTO dispute resolution as well, and this experience can prove important in preparing the resort for CIFA litigation to seek compensation for violations.

\section{E. INDONESIA'S NEW BIT MODEL PROPOSAL}

Some Asian countries rethink the costs and benefits of BIT and take various policy measures to protect themselves from expensive investor-state arbitration..$^{51}$ India, Pakistan and Indonesia are currently reviewing their old BIT texts and are preparing a new template model for future agreements. India launched a review of investment agreements in mid-2012 after the

\footnotetext{
$49 \quad$ Ibid.

50 Zoe Philips William, Rethinking Bilateral Investment Treaties, Netherlands: Both Ends, 2016, p. 29-30.

51 See Christine Côté, "A Chilling Effect? The Impact of International Investment Agreements on National
}

announcement of a public release of arbitration served by more than a dozen foreign companies. This notification challenges various policies (and court decisions) and demands Billions of dollars in compensation for alleged violations of Indian BIT. The purpose of this review is to revise the 1993 Indian agreement text model and to provide a roadmap for renegotiating existing BITs. Similarly, Indonesia is currently reviewing the BIT and FTA investment chapters that have been previously signed. ${ }^{52}$ Indonesia believes the current IIA regime does not provide sufficient space for the sustainable development and revisions needed to renew existing IIAs to defend the right to declare their regulatory space and policies. One of Indonesia's biggest concerns about IIA is the provision of ISDS, which has increased Indonesia's exposure to investor claims in international arbitration.

Indonesia's announcement to terminate more than 60 bilateral investment agreements (BIT) has triggered mixed reactions from academics and the business community around the world. This termination can further be known in the termination of Indonesia-Netherlands BIT which was already explained above. There is speculation that this was a spontaneous reaction by the Indonesian government, which recently faced several state-investor arbitration cases..$^{53}$ In fact, the announcement reminded us of the actions of several other governments that had stopped BIT or denounce the Investment Dispute Settlement

Regulatory Autonomy in the Areas of Health, Safety and the Environment", PhD Thesis in London School of Economics and Political Science, London: 2014.

52 Rubens Duarte, Loc.Cit.

$53 \quad$ Ibid. 
Convention between States and other Citizens (ICSID Convention) to reduce their legal exposure to international claims before the arbitration tribunal. In contrast, statements from Indonesian government officials show that they are going through a review of the country's BIT by allowing the old ones to disappear so that new and better ones can be renegotiated. This is mainly because the old one was concluded when the investment policy landscape was very different. Therefore, reviewing Indonesia's BIT will be timely. Existing clauses in Indonesia BIT is less clear and this has the potential to cause difficulties for the court in interpreting the provisions. It can also leave the court widely wisdom to interpret provisions, so as to make the state feel unjust bound by the 'imposed obligation' that they did not imagine when they were compile their IIA. The opportunity provided by the old BIT that has passed is also one that should be considered in depth about the need to provide policy space for the government, the importance of giving signals to foreign investors that Indonesia welcomes such investments, and the importance of protecting Indonesian investors when investing abroad. ${ }^{54}$

It is not much different from that made by other countries; BIT Indonesia generally contains various protections for investors and obligations for the host. Some clauses that can be found in Indonesian BIT include Fair and Equitable treatment (FET) and adequate protection and security; MFN, national treatment; not take over; compensation for losses, investment transfers and free returns,

\footnotetext{
$54 \quad$ S. L. Magaira, Loc.Cit
}

as well as settlement disputes.

${ }^{55}$ Theoretically, this agreement is reciprocal that applies to both parties, but because Indonesia's role in general has always acted as the host, foreign investors seem to get more benefits from BIT. Learning from BIT updated by many countries, there are some things that are recommended for Indonesia's BIT updates.

First, there is a need to reformulate decisively the definition of investment and investors. This formulation is very important to limit who can send disputes to the State Dispute Resolution Forum (ISDS) and what type of investment is covered by BIT. For investors, it is necessary to formulate a number of things (including Host-State subsidiaries from other Party entities? Should the entity maintain a presence in the Host Country? Are there some registrations or approvals needed?). Related to the definition of investment, there must be several explanations regarding several things (portfolio investment, bonds, securities, sales of goods or services, other contractual rights, loans, intellectual property rights). In the case of Rafat Ali Rivzi v. The Government of Indonesia, Indonesia rejects ICSID jurisdiction, because article 2.1 of the Indonesia-UK BIT states that investment protection is only given to "British citizens or companies ... who have been granted entry permits in accordance with Foreign Investment Law No. 1 of 1967 or any law that changes or replaces it. "We could find any definition investment in other new model of BITs. In Brazil's CIFA, the definition of

$55 \quad$ Karen Mills, Investor State Arbitration: Case StudiesIndonesia. International Investment Arbitration Training, 2018, p. 12. 
investment plays an essential role, since the CIFAs cover only FDI, which is the kind of investment seen as able to play a more decisive role in the development of the states. Portfolio investments are explicitly excluded from the scope of the CIFAs, since they encompass essentially short-term and speculative investment. ${ }^{56}$

Second, there is a need to reformulate the principles of Fair and Fair Treatment (FET). The majority of lawsuits filed by investors to ISDS use the argument that the host country has violated the Fair and Equitable Treatment (FET) standard. ${ }^{57}$ For example, in the case of Heslam, the plaintiff claimed that Indonesia violated the FET standard under the OIC Agreement. Furthermore, in the Rafat Ali case, Indonesia was prosecuted for violating Articles 4 and 2 (1) of the Indonesia-UK Bilateral Investment Agreement (BIT) concerning FET. Churchill Mining Plc. also uses FET violations in its lawsuit against Indonesia in 2015. In general, many IIAs, including Indonesian BITs, do not provide definitions of what is meant by FET Standards, even if BIT provides definitions, only open language. This condition tends to be interpreted broadly before the ISDS forum, so that almost all state actions that harm investors can be considered as violations of this standard. Unfortunately, the Brazil's CIFA does not contain this FET principle, but contain the corporate social responsibility. ${ }^{58}$ The national treatment clause and the

56 Riyatno, "Investment Dispute and International Arbitration", Paper presented at seminar Indonesia and The Development of International Arbitration in BANI, Jakarta: 2017, p. 66.

$57 \quad$ lbid.

58 Jason Webb Yackee, "Do States Bargain Over InvestorState Dispute settlement? Or Toward Greater Collaboration in the Study of Bilateral Investment nation's most favored treatment (MFN) in CIFA stipulates that foreign investors must be treated no less favorably than domestic investors or investors from third parties. Some of the exceptions are maintained, such as the prohibition of investment in the border region. This model does not limit the steps of new public policies, if not discriminatory. There are also articles on transparency, freedom of transfer related to investment, and articles on expropriation, which determine that direct expropriation is not permitted, except if carried out in the public interest, in a non-discriminatory manner, in accordance with legal processes and effective compensation payments. An important innovation in relation to other investment agreement models is the introduction of clauses on corporate social responsibility based on the OECD Guidelines for Multinational Enterprises, provisions on corruption and, in the latest negotiations, special exceptions for the protection of humans, animal and plant life. This is in line with Brazil's desire for investment to be socially responsible and contribute to sustainable development. ${ }^{59}$

Third, there is a need for Indonesia's New Model of BIT to prioritize the doctrine of solving local problems. The fatigue of the local solution doctrine gives investors' access to the ISDS when local solutions are inadequate. ${ }^{60}$ The local recovery doctrine was found in BIT from 1970-1980s. After 1980, this

Treaties", Santa Clara Journal of International Law, Vol. 12 , Issue 1,2013, p. 277-301.

$59 \quad$ Ibid.

60 See World Bank,"Indonesia Continues Strong Pace of Reforms to Improve Business Climate: Doing business", Press Release, 31 October 2017, 2018, accessed from https://www.worldbank.org/en/news/press- 
doctrine was not needed in BIT, and even many BITs strongly rejected this doctrine. An arbitration clause such as ICSID is interpreted as a rejection of the obligation of local recovery by parties in the BIT. A small number of BITs still need local settlement obligations but with a time limit of around eighteen months. Today, the doctrine of fatigue local solutions reappeared in the new BIT draft model released by India. A good example can be taken from the case of the Loewen Group v. the United States. In this case a Canadian funeral service operator (Raymond L. Loewen) claimed that his right to fair and equal treatment had been violated in the Mississippi Court, where he was ordered to pay hundreds of millions of dollars. The trial held under NAAA IIA rejected Loewen's claim because he had not submitted a claim to the U.S. Supreme Court. The benefits of applying fatigue to local solutions are to protect state sovereignty, as well as to help strengthen and integrate domestic and international systems for investor protection.

Fourth, BIT needs to request written approval from both parties before the ISDS mechanism is implemented. This is in line with the principle that applies in arbitration law that the arbitration jurisdiction is based on mutual agreement. In the case of Warraq, investors are citizens of Saudi Arabia and Indonesia does not have BIT with Saudi Arabia. Warraq brought the case to UNCITRAL based on the Agreement of the Organization of the Islamic Conference (OIC) in 1981. Indonesia objected to the jurisdiction of UNCITRAL based on the same arguments used

release/2017/10/31/indonesia-continues-strong-paceof-reforms-to-improve-business-climate-doing-business. 61 BKPM, Loc. Cit. in the Rafat Ali case. Indonesia also believes that based on the OIC Agreement, the forum for investors is a local court. However, the Court ignored this argument and claimed to have jurisdiction. Learning from this case, it is important to establish provisions for written approval from both parties in the BIT. ${ }^{61}$

Fifth, BIT needs to provide flexibility to the host country to protect the welfare of its people through non-discriminatory regulations for the purpose of public welfare, public health, safety, environmental friendliness, public morals or public order. CETA ensures investor protection, without ignoring the importance of protecting state sovereignty. This non-discriminatory provision has been also regulated in CIFA of Brazil. The Agreement contains a set of tools to mitigate investment risks and to avoid situations that may lead to formal disputes between the parties. Accordingly, the text lays downs guarantees of non-discrimination, such as national treatment and most favored nation principles, transparency provisions, as well as specific conditions for direct expropriation, compensation in case of conflicts and the free transfer of funds. ${ }^{62}$ As for the negotiation process, given the horizontal and multidisciplinary aspects related to investments and the intention to reach an understanding with its partners, the Brazilian government considers important and desirable to establish a dialogue involving, as much as possible, the various competent governmental bodies. ${ }^{63}$

\footnotetext{
62 Consideration of Cooperation and Investment Facilitation Agreement.

63 Ibid.
} 


\section{F. CONCLUSION}

Some aspects IIAs are very sensitive in Indonesia and in other countries, both developed and developing countries. One of the most debated issues related to investorstate dispute resolution (ISDS). Articles on ISDS are included in most BITs and RTAs such as NAFTA, ACIA, and TPP. ISDS allows foreign investors to bypass their host's domestic court system and submit a complaint with an international arbitration court. This is seen as a loss of national sovereignty over problems that occur within national borders. The financial risk of such claims can also exceed US \$ 1 billion. Because of these concerns, Indonesia has canceled many BITs for the past 2 years. But in what seems like a contradiction, Indonesia has performed a very similar obligation to approve the ISDS in ACIA and the ASEAN free trade agreement (FTA) with dialogue partners. Furthermore, President Joko Widodo has stated strongly interested in joining the TPP, which contains strong ISDS provisions. ASEAN Regional Comprehensive Economic Partnership (RCEP) is also likely to include ISDS.

Brazil is an interesting case study because this country is not involved in specific BIT but still receives a large amount of foreign investment. The country signed $14 \mathrm{BITs}$ in the 1990s, but the Indonesian National Congress Brazil refused to ratify them because of the potential risks associated with traditional ISDS systems. Lately, Brazil is reassessing its long-standing policy stance. In 2015, Brazil signed a Cooperation and Facilitation Investment Agreement (CIFA) with Mozambique, Angola, Colombia, Malawi and Mexico. This CIFA focuses primarily on investment cooperation and facilitation. By excluding state-investor arbitration, the CIFA promotes peaceful ways to resolve investment disputes. Martin Dietrich Brauch's paper provides an in-depth analysis of the CIFA of Brazil with Mozambique, Angola and Mexico. Given the growing criticism of the investor protection paradigm and weakness in investor state arbitration, Brauch explains how Brazilian CIFA is very different from the traditional BIT-ISDS regime.

By taking a look with Brazil's CIFA, we should conclude that the existence of the BITs is still important. However, Indonesia needs to update the BIT with new models that provide a balance between the interests of investors and the interests of the host country. Some Important changes recommended in the new BIT Indonesia model are as follows:

1. Redefining unclear terms that open up opportunities for interpretation that harm Indonesia. The terms referred to include investment and foreign investors.

2. Re-Formulation of Fair and Fair Treatment (FET) with clear standards.

3. Requires written approval from both parties to bring the dispute to international arbitration.

4. Providing flexibility to the state to protect public interests including human rights.

\section{REFERENCES}

\section{Books}

Adeleke, Folla, International Investment Law and Policy in Africa: Exploring a Human Rights Based Approach to Investment Regulation and Dispute Settlement, Roudledge, London, 2017. 
Bisaz, Corsin, The Concept of Group Rights in International Law, Martinus Nijhoff Publishers, Leiden, 2012.

BKPM, Development of investment and improvement agreements (P4M) and P4M settlement priorities between Indonesia-partner countries, Report, Jakarta, 2013.

Brown, Chester, Commentaries on Selected Model Investment Treaties, Oxford University Press, Oxford, 2013.

Chaisse, Julien and Tsai-yu Lin, International Economic Law and Governance: Essays in Honour of Mitsuo Matsushita, Oxford University Press, Oxford, 2016.

Das, Dilip K., Regionalism in Global Trade, Edward Elgar, Chaltenham, 2004.

Diel, Katharina, Towards Consistency of International Investment Jurisprudence, Koninklijke Brill, Leiden, 2017.

Douglas, Zachary (et.al), The Foundations of International Investment Law: Bringing Theory into Practice, Oxford University Press, Oxford, 2014.

Headley, James (et.al), Public Participation in Foreign Policy, Palgrave Macmilan, London, 2012.

Hindelang, Steffen and Markus Krajewski, Shifting Paradigms in International Investment Law: More Balanced, Less Isolated, Increasingly Diversified, Oxford University Press, Oxford, 2016

Hsieh, Pasha L. and Bryan Mercurio, ASEAN Law in the New Regional Economic Order: Global Trends and Shifting Paradigm, Cambridge University Press, Cambridge, 2019.

Krajewski, Markus and Rhea Tamara Hoffman, Research Handbook on
Foreign Direct Investment, Edward Elgar, Chaltenham, 2019.

Kulick, Andreas, Global Public Interest in International Investment Law, Cambridge University Press, Cambridge, 2012.

Levy, Daniel de Andrade, et.al (eds.), Investment Protection in Brazil, Wolters Kluwer Law and Business, Netherlands, 2013.

Mbengue, Makane Moïse and Stefanie Schacherer (et.al), Foreign Investment Under the Comprehensive Economic and Trade Agreement (CETA), Springer, Switzerland, 2019.

Mills, Karen, Investor State Arbitration: Case Studies-Indonesia. International Investment Arbitration Training, Daniel de Andrade Levy, et.al (eds.), Investment Protection in Brazil, Netherlands: Wolters Kluwer Law and Business, 2013.

Roberts, Anthea, et.al (eds.), Comparative International Law, Oxford University Press, Oxford, 2018.

Sauvant, Karl and Federico Ortino, Improving the International Investment Law and Policy Regimes: Options for the Future, Ministry of Foreign Affairs of Finland, Finland, 2013.

USA Global Investment Centre, Indonesian Investment and Business Guide, USA International Publications, USA, 2007.

Voss, Hinrich, The Determinants of Chinese Outward Direct Investment, Edward Elgar, Northampton, 2011.

Waibel, Michael (et.al), The Backlash Against Investment Arbitration. Perceptions and Reality, Kluwer, The Hague, 2010. 
William, Zoe Philips, Rethinking Bilateral Investment Treaties, Both Ends, Netherlands, 2016.

Yackee, Jason Webb, "Do States Bargain Over Investor-State Dispute Settlement? Or Toward Greater Collaboration in the Study of Bilateral Investment Treaties", Santa Clara Journal of International Law, Vol. 12, Issue 1, 2013.

\section{Other Documents}

Banga, Rashmi, Government policies and Investment Agreements on FDI inflows, Indian Council on International Economic Relations, India: 2003.

Barbosa, Daniel M C and Pedro Martini, "Two Sides of the Same Coin: To What Extent Is Arbitration with the Brazilian Administration Similar to InvestmentTreaty Arbitration?" in Andrade Levy, et.al (eds.), Investment Protection in Brazil, Netherlands: Wolters Kluwer Law and Business, 2013,

Brower, Charles N and Sarah Melikian, "We Have Met the Enemy and He Is Us! Is the Industrialized North Going South on Investor-State Arbitration?", 2015, p. 19; Catherine M Amirfar, "Treaty Arbitration: Is The Playing Field Level and Who Decides Whether It Is Anyway?" in Albert Berg, Jan van den (ed), Legitimacy: Myths, Realities, Challenges, Law International, The Hague, 2015.

Côté, Christine, "A Chilling Effect? The Impact of International Investment Agreements on National Regulatory Autonomy in the Areas of Health, Safety and the Environment", PhD Thesis in London
School of Economics and Political Science, London: 2014.

Duarte, Rubens, "The Role of Brazil in the Multilateral Financial System: An Analysis of Domestic and Structural Factors (2003-2015)", The Journal of the Brazilian Political Science Association, Vol. 11, Issue 3, 2017.

Garcia, Frank J. (et.al), "Reforming the International Investment Regime: Lessons from International Trade Law", Journal of International Economic Law, Vol. 18, Issue 4, 2015.

Gwynn, Maria A., "South American Countries' Bilateral Investment Treaties: A Structuralist Perspective", JIDS, Vol. 6, Issue 1, 2015.

Morosini, Fabio and Michelle raton Sanchez Badin, "The Brazilian Agreement on Cooperation and Facilitation of Investments: A New Formula for International Investment Agreements?", Investment Treaty News, 2014, acsessed from

https://www.iisd.org/itn/2015/08/04/t he-brazilian-agreement-oncooperation-and-facilitation-ofinvestments-acfi-a-new-formula-forinternational-investment-agreements/.

Nicolas, Françoise (et.al), "Lessons from Investment Policy Reform in Korea", OECD Working Papers on International Investment, Vol. 02, 2013.

Porterfield, Matthew C., "Exhaustion of Local Remedies in Investor-State Dispute Settlement: An Idea Whose Time Has come?", Yale Journal of International Law Online, Vol. 41, Issue 1, 2015.

Radi, Yannick, "Realizing Human Rights in Investment Treaty Arbitration: A 
Perspective from ithin the International Investment Law Toolbox", North Carolina Journal of International Law and Commercial Regulation, Vol. 3, Issue 1, 2012.

Riyatno, Investment Dispute and International Arbitration", Paper presented at seminar Indonesia and The Development of International Arbitration in BANI, Jakarta, 2017.

Schultz, Thomas and Cédric Dupont, "Investment Arbitration: Promoting the Rule of Law or Over-Empowering Investors? A Quantitative Empirical Study", European Journal of International Law, Vol. 25, Issue 4, 2014. Sornarajah, Muthucumaraswamy, The International Law on Foreign Investment, Cambridge University Press, Cambridge, 2010.

UNCTAD, "Reform of Investor-State Dispute Settlement: In Search of a Roadmap", Issues Note, No. 2, June 2013.

Vidigal, Geraldo, "Brazil's New Model of Dispute Settlement for Investment: Return to the Past or Alternative for the Future?", Journal of World Investment and Trade, Vol. 19, Issue 3, 2018.

Wälde, Thomas W, "Improving the Mechanisms for Treaty Negotiation and Investment Disputes: Competition and Choice as the Path to Quality and Legitimacy" in Karl P Sauvant (ed), Yearbook on International Investment Law \& Policy 2008-2009, Oxford University Press, Oxford, 2009.

World Bank,"Indonesia Continues Strong Pace of Reforms to Improve Business Climate: Doing business", Press Release, 31 October 2017, 2018, accessed from https://www.worldbank.org/en/news/pr ess-release/2017/10/31/indonesiacontinues-strong-pace-of-reforms-toimprove-business-climate-doingbusiness 